\title{
The Brazilian policy for reduction of accidents and violence aligns with international perspectives?*
}

\author{
A POLÍTICA BRASILEIRA DE REDUÇÃO DE ACIDENTES E VIOLÊNCIA SE ALINHA ÀS \\ PERSPECTIVAS INTERNACIONAIS?
}

\section{LA POLÍTICA BRASILEÑA PARA LA REDUCCIÓN DE ACCIDENTES Y VIOLENCIA SE ALINEA CON LAS PERSPECTIVAS INTERNACIONALES?}

\author{
Karen Namie Sakata1', Emiko Yoshikawa Egry², Nádia Zanon Narchi ${ }^{3}$
}

\begin{abstract}
The study analyzed The Brazilian Policy for Reduction of Morbidity and Mortality from Accidents and Violence, in the socio-political perspective. We used as a base the chapter "Violence: a global public health problem" from the World Report on Violence and Health. The analysis revealed convergent and divergent elements of the Brazilian Policy in comparison with the international perspectives. We verified that the Brazilian Policy tried to converge to the international policies, however: it emphasizes the health promotion actions, but are limited to the context and behavior of individuals and individual communities; the performance of health professionals is expected without providing more structural investments, as the improvement in work conditions, the increase of financial and material resources; there are few clear definitions of the government and economical sector responsibilities.
\end{abstract}

\section{DESCRIPTORS}

Violence

Public policies

Health policy

\section{RESUMO}

Analisou-se a Política Nacional de Redução da Morbimortalidade por Acidentes e Violência (PNRMAV) a partir de referenciais de análise de políticas públicas. Tomou-se por base o capítulo "Violência: um problema global de saúde pública", do Informe Mundial sobre Violência e Saúde. A análise revelou elementos de convergência e divergência da PNRMAV às perspectivas internacionais. Verificou-se que a PNRMAV buscou convergir às políticas internacionais, entretanto ela enfatiza as ações de promoção da saúde, mas são limitadas ao contexto e comportamento dos indivíduos e das comunidades individual. Espera-se o desempenho dos profissionais de saúde, todavia sem fornecer mais investimentos estruturais, como a melhoria das condições de trabalho, o aumento dos recursos financeiros e materiais. Há poucas definições claras das responsabilidades do governo e do setor econômico.

\section{RESUMEN}

Se analizó la Política Brasileña para la Reducción la Mortalidad y Morbilidad por Accidentes y Violencia (PNRMAV), a partir de los referenciales de análisis de políticas públicas. Se ha tomado en base al capítulo "La violencia: un problema mundial de salud pública" del Informe Mundial sobre la Violencia y la Salud. El análisis reveló elementos de convergencia y divergencia de perspectivas internacionales PNRMAV. Se encontró que la PNRMAV converge a la política internacional, sin embargo: Se hace hincapié en las acciones de promoción de la salud, pero se limitan al contexto más individual y de comportamiento de las personas y de las comunidades; Se espera el desempeño de los trabajadores de salud, sin proporcionar las inversiones más estructurales, como la mejora de las condiciones de trabajo, aumento de los recursos financieros y materiales; hay pocas definiciones claras de las responsabilidades del gobierno y el sector económico.

\section{DESCRITORES \\ Violência \\ Políticas públicas \\ Políticas de saúde}

\section{DESCRIPTORES \\ Violencia \\ Politicas publicas \\ Política de salud}




\section{INTRODUCTION}

Violence was probably always present in human history and its impact can be seen by many ways and in different parts of the world ${ }^{(1,2)}$. More than 1,6 million of people die in the world annually from violent acts and many other suffer non-fatal injuries resulting in a diversity of physical, sexual, psychological, social, reproductive and development problems ${ }^{(1,2)}$.

In 2000, the global estimative was 1.659 .000 of deaths related to violence. From those, 49,1\% (815.000 people) died from suicide, 31,3\% (520.000 people) died from homicide and $18,6 \%$ (310.000 people) died from events related to war ${ }^{(1,2)}$. It calls attention the information of $91,1 \%$ of total deaths were in low and middle income countries and, $8,9 \%$ happened in high income countries ${ }^{(1,2)}$. This information is an indication from an unequal distribution of violence in the world.

Besides the distribution regarding the income of countries, deaths caused by violence are also distributed differently in accordance with age group and gender, and it is one of the main causes of death in the population between 15 to 44 years old and responsible for $14 \%$ from dysfunctions in the male population and $7 \%$ in the female population $^{(1,2)}$.

As important as the classic divisions of people in income groups, gender and age group; it is also necessary to visualize the occurrence of events and deaths related to violence from social groups. Although this study does not address this theme directly, all considerations will be based in the Public Health perspective. Therefore, violence is defined here as a historical and social phenomenon and this is how it will be considered.

For that, it is highlighted that violence represents human costs as suffering and pain that cannot be calculated and in most of times, are invisible to the society, happening in private spaces as homes, workplaces and even in social institutions of health, protection, safety and legal; as hospitals, urgency and emergency services, police, courts, shelters, asylums, jails, within many others ${ }^{(1,2)}$.

And as human costs, there are losses and economical costs, which in fact, seem to call attention and to arouse the concern of a global situation that lives and survives under a capitalism model of production.

Economic costs are translated in billions of dollars annually with health and legal costs, besides the losses in terms of productivity with absent days and costs from the population affected by violence, especially, the population in productive years and active to work ${ }^{(1,2)}$.

Violence is defined by the World Health Organization (WHO) as "the intentional use of physical force or power, threatened or actual, against oneself, another person, or against a group or community, that either results in or has a high likelihood of resulting in injury, death, psychological harm, maldevelopment, or deprivation"(1 p5). The definition comprehends the interpersonal violence as the suicidal behavior as well as armed conflicts. Besides that, the introduction of the word "power" amplifies the definition of violence when considering more than lesions and physical damages, but also including threats and intimidations. Independently of the produced results, violence is the action and the intention to provoke it, as well as negligence acts, omissions and all types of abuse (sexual, psychological and physical) ${ }^{(1,2)}$.

From this most amplified picture about violence and the WHO's definition that we aimed to comprehend the Brazilian Policy for Reduction of Morbidity and Mortality by Accidents and Violence (PNRMAV)(3) - with emphasis to violence - in its alignment to international perspectives and to discuss about some repercussions regarding its operationalization.

\section{METHOD}

Based on the social politics analysis proposal by Fleury and Overney in $2012^{(4)}$, the alignments analysis of the (PNRMAV) $^{(3)}$ was performed with the international perspectives presented in the chapter "Violence: a global public health problem" from the World Report on Violence and Health(2).

For this analysis, the seven aspects or essential dimensions in the building and in the dynamics of health policy management, proposed by Fleury and Overney ${ }^{(4)}$.

The first aspect refers to the objectives definition or policy purpose, guided by greater values and that determine how resources are allocated, the strategies, the plans and the instruments to be adopted, and later evaluated. This dimension gives visibility, it facilitates the disseminations of reached achievements, it allows broaden vision and, facilitates the policy evaluation process ${ }^{(4)}$.

The second, refers to the creation and implementation of strategies, plans and instruments. It refers also to Instrumental aspects that allow a more concrete vision of the policy, its principles and thematic nucleus; the actions to be performed; the expected results; the responsible for its execution; the volume of available resources and its origin; and, the indicators that will be used to evaluate its execution. This dimension allows comprehending not only the social policy plan of action but also its articulation with reality; that allows more concrete delimitation of potentials and limitations ${ }^{(4)}$.

The third aspect is related to the simultaneous performance of different political and economic roles, that is, to the political and economic effects caused by social policies in the economic scope, once it moves financial resources, produces goods and services, defines acting areas and priorities, among others ${ }^{(4)}$.
The Brazilian policy for reduction of accidents and violence aligns with international perspectives? Sakata KN, Egry EY, Narchi NZ 
The fouth refers to the official creation of arenas, channels and routines to guide decision-making processes, that define plans, programs, strategies and policies resources allocation and that are influenced by the power relationships and interests of many involved subjects. Those relationships give structure to the general policy format and are expressed by established norms in institutional environments of pact and establishment of agreements called arenas. In the scope of the Brazilian Health System (SUS), for example, this dimension refers to the mechanisms of participation and social control (especially health conferences and councils) and the mechanisms of negotiation and pacts between the governmental agencies (health consortiums within municipal managers, bipartite and tripartite interagency commissions) $)^{(4)}$.

The fifth aspect refers to the assimilation, counter position and/or compatibility of different social projects. As intense dynamic of power relationships, the health policy is also an expression of strength from political fights of different projects and social proposals, that involves social macro processes (political, economic, ideological and social organization models) resulted from interest confronts, disputes and mediated by power relations $s^{(4)}$.

The sixth aspect refers to the development, reproduction and transformation of institutional frameworks. The social demands that are transformed into public policies are institutionalized and shape the institutional frameworks. In other words, the state apparatus is materialized in institutions, organizational structures, human and technical capacity, laws, practices and procedures. The institutional frameworks are also called as policies regulators, because at the same time that they sustain actions and programs, they also regulate and limit those ${ }^{(4)}$.
The seventh and last aspect refers to the creation of theoretical and valuable references of social life. In this dimension, the diffusion of information and values by social policies also influence behaviors, patterns and cultural habits, relations of political organization, the perception of people about themselves and the construction of social relationships in the family, at work and in community spaces. The social policies therefore, boost a redefinition process, production and appropriation of new social meanings, concepts, values and cultural references that will also generate impacts in the social structure ${ }^{(4)}$.

To perform the proposed analysis in this study, the presence of the seven dimensions were identified as proposed by Fleury and Ouverney ${ }^{(4)}$ for the national policy as well as for the world report, that allowed the comparison and reflection regarding the Brazilian policy alignments to the international perspectives.

After the PNRMAV analysis in accordance with the seven dimensions $\mathrm{s}^{(4)}$ and its alignments to the international perspectives using as reference the World Report, it was discussed regarding some repercussions about the operationalization of the PNRMAV, using experiences described in the scientific literature ${ }^{(4)}$

\section{RESULTS}

The results are organized in Table 1 in accordance with the dimensions of analysis of social policies proposed by Fleury and Ouverney ${ }^{(4)}$. Parts of the PNRMAV the World Report on Violence and Health are available in full or interpreted, side by side in the table for posterior comparison and reflection

Table 1 - Alignment of the brazilian national policy for reducton of morbidity and mortality by accidents and violence with the wolrd report on violence and health, in accordance with the proposed dimensions by Fleury e Ouverney ${ }^{(4)}$.

\begin{tabular}{|c|c|}
\hline $\begin{array}{l}\text { Brazilian National Policy for Reduction of Morbidity and Mortality } \\
\text { by Accidents and Violence }\end{array}$ & World Report on Violence and Health \\
\hline \multicolumn{2}{|c|}{ OBJECTIVES/PURPOSES } \\
\hline $\begin{array}{l}\text { "reduction of morbidity and mortality by accidents and violence in the } \\
\text { country, through the development of a group of articulated and systematic } \\
\text { actions, to contribute for the quality of live of the population" (p. 24) }{ }^{(3)} \text {. }\end{array}$ & $\begin{array}{l}\text { The essence of the document is the prevention of violence. More than } \\
\text { reacting towards violence, the conviction is that a violent behavior and } \\
\text { its consequences can be prevented and avoided }{ }^{(2)} \text {. }\end{array}$ \\
\hline \multicolumn{2}{|c|}{ CREATION AND IMPLEMENTATION OF STRATEGIES, PLANS AND INSTRUMENTS } \\
\hline $\begin{array}{l}\text { There is emphasis for the importance of health promotion, but it } \\
\text { defines guidelines only for actions of violence already installed. The } \\
\text { health promotion seems to be understood in the particular scope of the } \\
\text { individual, for example, adopting "healthy habits and lifestyles" (p. 23) } \\
\text { (3). The guidelines are: } \\
\text { - "promotion of adoption of healthy and safe behaviors and environments; } \\
\text { - monitoring occurrences of accidents and violence; } \\
\text { - to create a system, to amplify and consolidate pre-hospital care; } \\
\text { - structuration and consolidation of care for recovery and rehabilitation; } \\
\text { - human resources capacity; and } \\
\text { - support to studies and research development" (p. } 25)^{(3)} \text {. }\end{array}$ & $\begin{array}{l}\text { "Public Health approach with collective and interdisciplinary actions and } \\
\text { with prevention emphasis }{ }^{(2)} \text { : } \\
\text { - to examine and create a system with the highest possible number of } \\
\text { knowledge about violence; } \\
\text { - to perform research to determine violence causes and factors; } \\
\text { - to explore ways to prevent violence; } \\
\text { - to disseminate information and promising interventions, determining } \\
\text { the programs costs and efficacy" (p.1165) })^{(2)} \text {. }\end{array}$ \\
\hline
\end{tabular}


- Definition of federal, state and municipal managers' responsibilities.

- It gives dimension to the economic impact in terms of costs with health care (costs with hospitalizations) and losses of workforce in the economically active population.

- It does not define the economical sector role ${ }^{(3)}$
It gives dimension to the economic costs of violence in terms of health care, absent days at work, imposition and compliance of laws and lost investments ${ }^{(2)}$.

\section{OFFICIAL CREATION OF ARENAS, CHANNELS AND ROUTINES TO GUIDE DECISIVE PROCESSES}

- Violence is understood as a phenomenon which can be prevented, although there are no clear guidelines to act in this scope.

- Specific arenas where decisive processes can happen are not defined, beyond those constituted in the Unified Health System (SUS), for example, the counsils, the conferences and the health consortiums between municipal managers, the bipartite inter managers comission and the tripartite inter managers comission ${ }^{(3)}$.
"The lack of knowledge about violence and the false sensation of peace and safety when a major part of violence is hidden, leads to many authorities and people in decisive positions to not consider violence as a public health problem neither as a preventable event. A major part of people considers violence as a criminal problem and the only effective approaches are those traditional ones of the judicial system" (p.1176) ${ }^{(2)}$.

\section{ASSIMILATION, COUNTER POSITION AND/OR COMPATIBILITY OF DIFFERENT SOCIAL PROJECTS}

-"Incorporation of new guidelines to face and make adjustments dictated by practice" (p.49)

"The follow-up and assessment of actions can be done with data and information generated by different programs, plans, projects or activities which will be operationalized from this Policy" (p. 49) ${ }^{(3)}$;

- Follow-up and assessment of achievement of goals and nationals and international commitment.

"More innovative solutions have been coming from the community and from local levels of government, exactly those closer to the problem in a routine basis" $(\mathrm{p} .1176)^{(2)}$

\begin{tabular}{|c|c|}
\hline \multicolumn{2}{|c|}{ DEVELOPMENT, REPRODUCTION AND TRANSFORMATION OF INSTITUTIONAL FRAMEWORKS } \\
\hline $\begin{array}{l}\text { Intrasectoral actions from SUS and intersectoral actions with } \\
\text { governmental and non-governmental segments }{ }^{(3)} \text {. }\end{array}$ & $\begin{array}{l}\text { Multisectoral approaches in local/community, regional and international } \\
\text { levels }^{(2)} \text {. }\end{array}$ \\
\hline \multicolumn{2}{|c|}{ CREATION OF THEORICAL AND VALUABLE REFERENCES OF SOCIAL LIFE } \\
\hline $\begin{array}{l}\text { - "health constitutes a fundamental human right for the social and } \\
\text { economic development; } \\
\text { - the right and respect for life configure ethical values of culture and } \\
\text { health; and } \\
\text { - health promotion should base all plans, programs, projects and activities } \\
\text { to reduce violence and accidents" (p. 24)(3). }\end{array}$ & $\begin{array}{l}\text { "Health and well-being of populations and safety and healthy communities } \\
\text { around the world" (p. 1176) })^{(2)} \text {. }\end{array}$ \\
\hline
\end{tabular}

\section{DISCUSSION}

\section{The National Policy for Reduction of Morbidity and Mortality by Accidents and Violence and its alignments to the international perspectives}

A social policy is a policy aimed to the reproduction of individuals and collectivities guided in well-being and social protection. It acts concretely in the social reality by complex and multifaceted dynamic, distributing resources and opportunities, promoting equity and citizen rights and affirming human values as ideal and reference for society organization. One of the important aspects is to be oriented by values even when in most cases its final objectives are not in fact corresponded to the initial proposed objectives. This happen because there are many interests and the involved determinants in the creation and implementation of a policy, as well as in the imposed conditions by bureaucracy for management and effectiveness of diverse social policies for health, education, housing, pension funds and social assistance ${ }^{(4)}$.

To systematize the analysis of a determined social policy allows a better comprehension of its elements, how to operationalize those in practice or how they could be operationalized considering its potentials and limitations.
It was verified that the PNRMAV is composed of elements that allow the analysis by the defined propose of Fleury e Ouverney ${ }^{(4)}$.

From the resulted analysis with emphasis in violence, it was observed that the PNRMAV is focused in the reduction of morbidity and mortality from violence while the World Report focuses in the prevention of violent behaviors, more than reacting to them.

The World Report document highlights the Public Health and its rigorous requirements of scientific method as a privileged knowledge field to deal with violence, once it represents a global public health problem and require an approach based in interdisciplinary collective actions with emphasis in prevention ${ }^{(2)}$. On the other hand, the PNRMAV defines its strategies, plans and instruments with emphasis in intervention actions in the situation of violence already installed, for example, during recovery and rehabilitation. As important as the direct actions in the occurred situation, are the prevention actions of violence and its consequences and the health promotion. The health promotion actions designed in the PNRMAV guidelines stay restricted to the most individual scope and personal and community behavior, and many initiatives 
are expected from health professionals, not having more structured bases for actions and changes, as well as working conditions and the financial and material resources designated to the development of actions. On the other hand, this can reveal that it is not possible to reach total compatibility with global guidelines to guide national policies once realities are really diverse and heterogeneous.

The deficiencies and fragilities in violence prevention are also identified in public policies and in health systems of other countries, that answer to a dichotomous violence model and, sometimes, the health system itself does not have violence as priority, being the emphasis given by the judicial system and getting diffuse the role of the sanitary system ${ }^{(6)}$.

The PNRMAV defines economic sector managers' responsibilities and highlights the preoccupation with the impact that the violence situation and accidents can generate in the economy in terms of costs with health care and losses in workforce. Thus, the World Report also presents an explicit preoccupation with the economic impact generated with the violence situation worldwide.

Regarding the dimension of official creation of arenas, channels and routines to guide the decisive processes, in Brazil, spaces to support decisive processes are guaranteed by SUS, for example, the conferences and health councils and the inter manager commissions ${ }^{(4)}$. In an international scope, the presented situation by the World Report is about the lack of knowledge of the real situation of violence by many people and authorities that end up understanding violence as a question of only judicial and criminal scope ${ }^{(2)}$.

The assimilation, counter position and compatibility of different social projects appears in the PNRMAV as a possibility to rearrange and readjust in its own Policy by State mechanisms: the practice, programs and the achievement of national and international goals ${ }^{(3)}$. Projects constituted in and about the community are not mentioned. The World Report refers to innovations from the communities and local governments that suffer directly with violence consequences ${ }^{(2)}$.

In the dimension of development, reproduction and transformation of institutional frameworks; the NPRMMAV and the World Report seems to be aligned in relation to actions that are multi or inter sectorial ${ }^{(2,3)}$.

In the creation of theorical and valuable references of the social life, the World Report brings health and wellbeing as value for the world population ${ }^{(2)}$. The PNRMAV reinforce the constitutional achievement from SUS, being health considered a right ${ }^{(3)}$. It incorporates the idea of health as a right for social development, but also economic. It considers the right and respect to life as ethical values and, again, it highlights health promotion as an important element to base actions to reduce violence, without letting it clear what would be those actions and how and with which resources (financial and human) it would be operationalized.
There is a strong uproar to fight violence and it is reinforced by the fact that it is a situation with a series of human and ethical values. However, as needed as the postures and individual behavior based in ethical and human values, broader actions defined in policies and under the responsibility of State and governors. From that, there is a need to formulate clear and coherent policies to sustain actions, determining guidelines and guaranteeing the real conditions for its implementation to transform the objective reality.

In a study of systematic review, the impacts of the world economic and financial crises of 2008 on children's health were discussed. Within the findings, there was the increase in infant deaths in African countries and in Greece and the increase of nutritional risks (obesity and malnutrition). Due to the increase in food prices in crisis situations that reduce the nutritional diversity and quality of diets, being the vulnerable groups the most affected, as the poorer populations in urban areas in developed or developing countries. Another finding related to the violence situation against children, who are direct or indirectly affected when mental problems, stress, suicides and violence affects in higher number families during crisis periods. Previous experiences also provided evidence that protection actions developed by a wellbeing State, and that kept during a crisis period, were effective, not having negative impacts or having minimum impacts on children's health ${ }^{(7)}$. This reinforces the importance to formulate policies that are capable to interfere in social determinants to reduce inequities in health and the inequities that structures the capitalism society.

\section{Some repercussions in the National Policy for Reduction of Morbidity and Mortality by Accident and Violence}

In a study conducted by the Latin American Center of Studies on Violence and Health (Claves/Fiocruz) ${ }^{(5,8)}$, in 2007 , in partnerships with research center of five Brazilian capitals (Rio de Janeiro, Recife, Manaus, Curitiba and Brasília), information was brought regarding the morbidity and mortality from violence and accidents situation; the adequacy of mobile and fixed services pre-hospitalization, hospital, rehabilitation and promotion services; professional training specific for dealing with this issues; surveillance, monitoring and support for studies and research on this theme. This study showed important advances in the health system organization in some Brazilian capitals due to the PNRMAV. Examples of advances: the mobile urgent care and the study nucleus and programs specifically to deal with violence. As some barriers to be surpassed: the disarticulation of the health network and the communication between managers in diverse instances of SUS management, the lack of conditions to work represented by the low number of workers and material resources and the lack of investments in the health sector ${ }^{(5,8)}$.

Analyzes about the implementation of PNRMAV in those five Brazilian capitals called attention for the prac- 
tices performed in different ways, although directed by a national policy. It happens due to the fact of dealing with different realities that interpret and operationalize differently a policy through subjects that are also different among themselves ${ }^{(9)}$.

Therefore, the PNRMAV analysis done in this article also did not have the goal to represent priorities to be adopted for the operationalization of this policy, also, it did not designed a pattern of how it should be interpreted and implemented. Still, the intention was to propitiate a systematic analysis of the PNRMAV and, while trying to understand the alignments of those international perspectives, it was possible to identify internal contradiction in the PNRMAV itself: although its goal is to reduce the morbidity and mortality of those aggravations, there are emphasis for the health promotion actions designed in the PNRMAV guidelines, but those are regarding the most individual and behavioral aspect of people and communities, being many initiatives expected in the action of health professionals without prevising more structured contributions, as improvements in work conditions and increase in financial and material resources ${ }^{(3)}$.

Before discussing the repercussions in the PNRMAV operationalization, in this context, it is fundamental to reflect about the political and decisive pattern currently adopted by the Brazilian State that seems to be based more in the adoption of palliative measures in relation to the violence situation.

It was observed that the PNRMAV comes from the possible perspective in which the creation of this social policy was centered in the society and, for that reason, it is permeable to interests and competitions between interested groups much more in the reduction in the morbidity and mortality indexes provoked by violence than for its broad prevention, based in structural determination done by the State and the social functioning. It would remain to know better the imposed conditionings by the bureaucracy for the implementation process of this health policy, as well as, the way it is articulated with the economic policy or it dependent from it to be formulated. Based in this reflection, it is needed to advance in studies that allows more precise analysis of the decisive processes and the intermediation of interests involving the health sector in $\operatorname{Brazil}^{(10)}$.

The PNRMAV shows that it was formulated to attend the Brazilian population demand by violence eradication, without being established fundamental criteria for its prevention, that is, acting upon the social determinants with integrated action of improvement in education, transportation, housing, health, among others.

This implicates in repercussions in the PNRMAV operationalization, and some can be discussed from experiences with evidence in the study conducted by Claves ${ }^{(8)}$ : the absence of attention and assistance to families in the practice of health services in any level of attention, with exception to the Curitiba, in which $58 \%$ of studied units were attentive to the inclusion of families of people who suffered with aggravations of accidents and violence; a few explored possibilities of interaction with diverse social sectors (schools, universities, non-governmental organizations, community groups, etc.); disarticulation in the reference and counter reference system among the diverse equipment of the health network; inexistence or lack of actions registries of prevention and health promotion in the hospital scope; deficiencies in the composition of multidisciplinary teams and lack of specialized professionals; attention of accidents and violence still centered in the traditional attention model and focused on medical and biological care, not advancing to the health character as civil rights; among others ${ }^{(8,11)}$.

"Preventive actions still are very little thought, institutionalized and undertaken. Our research show that only half of services that attended the victims of accidents and violence cares about this important action that are centered on the PNRMAV, that put as its main guideline the promotion of quality of life and not only the treatment of aggravations"(8 p1645).

Even that the prerogative of the Family Health Strategy being responsible by the longitudinal follow-up of users and their families in the health attention network with focus on the prevention and in health promotion and, still with the basic units being highlighted due to the promotion of the referral and follow-up of cases, it is observed the disarticulation and discontinuity in the care when the flaws in the counter-reference via are perpetuated ${ }^{(8)}$.

Added to it, a certain naturalization of indifference and devaluation attitudes with the prevention and health promotion actions, reflecting in the little knowledge of the importance of these actions by the population and in low public investments in the scope of the Primary Health Care.

There are discrepancies between the legislation and the public investments and the global influences about the society organization and national politics. This affects, overall, specially in strategic areas of political actions, as education and health; will be about those who give the quality rhythm of the actions performed, that is, on the professionals ${ }^{(12)}$. At a national level, education and health are precarious areas due to the lack of public investment that have been given little value to their professionals, once, depending on the political moment and the government plans, suffer with the speculation of the neoliberal market that make precarious the work processes and force to a transformation of fundamental rights in goods to generate profits.

As seen, although the well succeed and successful experiences in the PNRMAV implementation, a significant number of actions designed by PNRMAV are not still implemented or face major difficulties to be truly effective, as the case of preventive actions of aggravations and
The Brazilian policy for reduction of accidents and violence aligns with international perspectives? Sakata KN, Egry EY, Narchi NZ 
health promotion, that exemplify the repercussion in the internal contradiction of the PNRMAV that emphasizes the importance of health promotion, but does not foresee more structural changes, as the increase of political and financial investments in this area.

\section{CONCLUSION}

The reflection about the PNRMAV to Reduce Morbidity and Mortality by Accidents and Violence, looking for its alignments to the international perspectives based in the comparison with the World Report on Violence and Health, gave the possibility to better understand how the international agencies influence the definition of legislation in other countries, more specifically in the direction related to the violence in Brazil.

Many convergent and divergent elements between the PNRMAV and the World Report were found. The main divergence is about the emphasis in prevention strongly announced in the World Report and almost does not appear in the PNRMAV that has as major objective the reduction of morbidities and mortalities caused by violence, intervening in the situations already installed. From this point, it was possible to identify an internal contradiction in the PNRMAV that emphasizes the actions of health promotion, but present guidelines for individual initiatives, attitudes and behaviors of people, communities and

\section{REFERENCES}

1. Krug EG, Dahlberg LL, Mercy JA, Zwi, AB, Lozano, R. Violence: a global public health problem. Geneva: WHO; 2002. World report on violence and health; pp. 3-21.

2. Dahlberg LL, Krug EG. Violence: a global public health problem. Cien Saude Colet. 2007;11(sup):1163-78.

3. Brazil. Ministry of Health. Portaria GM/MS n. 737, de 16 de junho de 2001. National Policy for Reduction of Morbidity and Mortality from Accidents and Violence. 2ª ed. Brasília; 2005.

4. Fleury S, Ouverney AM. Health policy: a social policy. In: Giovanella L, Escorel S, Lobato LVC, Noronha JC, Carvalho AI, organizadores. Policies and health system in Brazil. Rio de Janeiro: Ed. Fiocruz; 2012. pp. 25-57.

5. Minayo MCS, Deslandes SF. Analysis of the implantation of the healthcare nework for victims of accidents and violence following the guidelines of the National Policy for the Reduction of Morbidity and Mortality from Violence and Accidents. Cienc Saude Colet. 2009;14(5):1641-49.

6. Loría KR, Rosado TG, Espinosa LMC, Marrochi, LM, Sánchez, AF. Trends in public health policies addressing violence against women. Rev Saude Publica. 2014;48(4):613-21. health professionals, without foreseeing more structural changes in the health system organization and other society sector, as the improvements in the work conditions and increase in financial resources.

This contradiction has implications in the PNRMAV operationalization on national scope as evidence provided from the study conducted by Claves $^{(8)}$ and presented in this article as elements to exemplify the discussion. Within many successful experiences and the limitations for the effective PNRMAV implementation, one of the main contradictions found in its operationalization and that is a reflection of the own identified PNRMAV contradiction, was the existence of few actions designated to the prevention of this aggravations and the health promotion, being in the dimension of construction and implementation of strategies, plans and instruments; in which the PNRMAV was analyzed; the main emphasis was given to the importance of health promotion actions.

To comprehend the PNRMAV, in a sense of investigate the alignments to the international perspectives and looking for the repercussions in the operationalization of this policy in the country, leaves open the possibility (and importance) to reproduce with other policies this and other analysis proposes of this type. It remains evident the necessity to develop studies to give support to produce polices potentially stronger to transform the violence reality in the world and in Brazil.

7. Rajmil L, Sanmamed MJF, Choonara I, Faresjo, T, Hjern, A, Kozyrskyj, AL, Lucas, PJ, Raat, H, Séguin, L, Spencer, N, Taylor-Robinson, D. Impact of the 2008 economic and financial crisis on child health: a systematic review. Int J Environ Res Public Health. 2014;11:6528-46.

8. Lima MLC. About the National Health Policy for Reducing Accidents and Violence nowadays. Cien Saude Colet. 2009;14(5):1654-55.

9. Moysés SJ. Krempel MC. Dialoguing on the implementation of the National Policy for the Reduction of Morbidity and Mortality from Violence and Accidents in five Brazilians capitals. Cien Saude Colet. 2009;14(5):1652-54.

10. Viana ALA, Baptista TWF. Analysis of health policies. In: Giovanella L, Escorel S, Lobato LVC, Noronha JC, Carvalho Al, organizadores. Policies and health system in Brazil. Rio de Janeiro: Ed. Fiocruz; 2012. p. 59-87.

11. Melo E. Resenha: Diagnostic analysis of the National Health Policy for the Reduction from Accidents and Violence. Cad Saude Publica. 2008;24(7):1717-18.

12. Cavalcanti MLT. The analysis of the implementation of the National Policy for the Reduction of Morbidity and Mortality from Violence and Accidents highlights the problems at the Unified Health System. Cien Saude Colet. 2009;14(supl.1):1650-51. 